\title{
Gemcitabine-based chemotherapy in colon squamous cell carcinoma: A case report and literature review
}

\author{
SHUFEN ZHAO* , JING GUO*, LIBIN SUN, JING LV and WENSHENG QIU* \\ Department of Oncology, The Affiliated Hospital of Qingdao University, Qingdao, Shandong 266003, P.R. China
}

Received July 27, 2016; Accepted February 17, 2017

DOI: $10.3892 / \mathrm{mco} .2017 .1178$

\begin{abstract}
Squamous cell carcinoma (SCC) originating from the colon is rare. In terms of its clinicopathological characteristics, this type of cancer has been reported to be more aggressive and have a worse prognosis compared with adenocarcinoma. We herein present a successful therapeutic approach applying neoadjuvant and adjuvant gemcitabine-based chemotherapy in a patient with colon SCC. A 58-year-old male patient received two cycles of neoadjuvant chemotherapy with a regimen including gemcitabine, oxaliplatin and capecitabine, followed by radical excision and six cycles of adjuvant chemotherapy. Contrast-enhanced computed tomography and serum tumor markers were used for reassessment and evaluation was based on the World Health Organization criteria. Following neoadjuvant chemotherapy, the mass had shrunk and the patient was classed as having stable disease. Surgery and adjuvant chemotherapy were then performed and the patient had achieved a progression-free survival of 10 months when this report was submitted. Therefore, gemcitabine may be a treatment option for colon SCC in the neoadjuvant and/or adjuvant chemotherapy setting.
\end{abstract}

\section{Introduction}

Colon cancer is one of the most common cancers worldwide, with the predominant type being adenocarcinoma (1). Squamous cell carcinoma (SCC) of the colon is a rare pathological type, representing $\sim 0.06 \%$ of all colorectal malignancies (2). The clinical characteristics of colon SCC are similar to those of adenocarcinoma. The treatment of SCC is mainly surgical resection. In terms of chemotherapy, there is currently no standard regimen for the treatment of

Correspondence to: Professor Wensheng Qiu, Department of Oncology, The Affiliated Hospital of Qingdao University, 16 Jiangsu Road, Qingdao, Shandong 266003, P.R. China

E-mail: wsqiuqd@163.com

*Contributed equally

Key words: colon cancer, squamous cell carcinoma, gemcitabine, chemotherapy colon SCC and its prognosis has been reported to be worse compared with that of adenocarcinoma. We herein present the case of a 58-year-old male patient diagnosed with adenosquamous carcinoma of the colon, who was treated with systemic gemcitabine-based neoadjuvant chemotherapy, followed by surgery and adjuvant chemotherapy.

\section{Case report}

A 58-year old male patient was hospitalized with a 5-month history of abdominal pain accompanied by a mass in the right lower quadrant. The symptoms gradually worsened and the patient experienced hematochezia, anorexia and weight loss of $\sim 10 \%$ body weight. The patient had a history of smoking and alcohol consumption.

The contrast-enhanced computed tomography (CT) scan revealed a mass located in the lower part of the ascending colon. On enteroscopy, space-ocuppying lesions were identified in the rectum and ascending colon. The result of the pathological examination of the rectal lesion was moderately differentiated adenocarcinoma, while sampling from the colon was unsuccessful. In order to obtain a sample from the lesion of the ascending colon, the patient underwent CT-guided biopsy twice. The first time the pathology result was poorly differentiated carcinoma, while the immunohistochemistry findings were consistent with adenosquamous carcinoma with a predominant SCC component, whereas the second biopsy was used for verification due to the atypical pathological characteristics (Table I).

After excluding distant metastasis by thoracic CT, whole-abdomen CT, whole-body bone scan emission computed tomography and head magnetic resonance imaging, the patient received neoadjuvant chemotherapy. The chemotherapy regimen was designed based on the therapeutic regimen for adenocarcinoma and the poor prognosis of this pathological subtype. The chemotherapy was conducted every 21 days and included gemcitabine $\left(1,000 \mathrm{mg} / \mathrm{m}^{2}\right.$ intravenously, $1,800 \mathrm{mg}$ on $\mathrm{d} 1$ and $1,600 \mathrm{mg}$ on $\mathrm{d} 8)$, oxaliplatin $\left(130 \mathrm{mg} / \mathrm{m}^{2}\right.$ intravenously, $200 \mathrm{mg}$ on $\mathrm{d} 1)$ and capecitabine $\left(625 \mathrm{mg} / \mathrm{m}^{2}\right.$ orally, 1,000 mg bid on days d1-14). The capecitabine dose was reduced by $50 \%$ in order to avoid severe side effects. Between August 18th, 2015 and September 24th, 2015, the patient received two cycles of neoadjuvant chemotherapy. Contrast-enhanced CT (Fig. 1) and measurement of tumor marker serum levels were used to evaluate treatment effi- 
Table I. Pathological characteristics of the tumors.

A, Pathology of the colon tumor

\begin{tabular}{|c|c|c|}
\hline 1st CT guided biopsy & 2nd CT guided biopsy & Surgery \\
\hline $\begin{array}{l}\text { Poorly differentiated carcinoma, } \\
\text { tumor cells arranged in nests, } \\
\text { partially seen intercellular junctions. } \\
\mathrm{CK}^{+}, \mathrm{P} 63^{+}, \mathrm{Syn}^{-}, \mathrm{CgA}^{-}, \mathrm{CD}^{-}, \mathrm{CK}^{+} \text {, } \\
\mathrm{CK}^{-} 0^{-}, \mathrm{CDX}^{-} 2^{-}, \mathrm{GATA}^{-} 3^{-}, \mathrm{Ki}-6770 \%\end{array}$ & $\begin{array}{l}\text { Poorly differentiated carcinoma, } \\
\text { consistent with adenosquamous carcinoma } \\
\text { with a predominant SCC component. } \mathrm{P}^{+} \text {, } \\
\quad \mathrm{P} 40^{+}, \mathrm{CK}^{+}, \mathrm{CK} 20^{-}, \mathrm{CDX}^{-} 2^{-}, \mathrm{Syn}^{-}\end{array}$ & $\begin{array}{l}\text { Poorly differentiated SCC } \\
\text { (ulcerative type) with involvement } \\
\text { of outer serosal fat and vessels, } \\
\text { with or without PNI. Infiltration } \\
\text { of pericolic lymph nodes }(1 / 22) \text {. } \\
\text { CK } 5 / 6^{+}, \mathrm{P}^{+} 0^{+}, \mathrm{P}^{+}, \mathrm{CK}^{+} \text {(partly) } \\
\text { CK } 20^{-}, \mathrm{CDX} 2^{-}, \mathrm{Syn}^{-}, \mathrm{CD} 31^{+} \\
\text {(indicating vascular invasion) }\end{array}$ \\
\hline
\end{tabular}

B, Pathology of the rectal tumor

Endoscopic biopsy

Rectal adenocarcinoma
Surgery

Moderately differentiated adenocarcinoma (ulcerative type) with serosal involvement, without resection margin involvement. Perirectal lymph nodes free of metastasis (0/13). PMS-2+, $\mathrm{MLH}^{+}$, MSH2-, MSH6- Her-2 (0), S-100 (neural invasion), CD31 ${ }^{+}$ (indicating extensive vascular invasion), Ki $6780-90 \%$.

CT, computed tomography; SCC, squamous cell carcinoma; CK, cytokeratin; Syn, synaptophysin; CgA, chromogranin A; CDX-2, caudal type homeobox 2; PMS-2, mismatch repair endonuclease PMS 2; MLH1, mutL homolog 1; MSH, mutS homolog; Her-2, human epidermal growth factor receptor 2 .
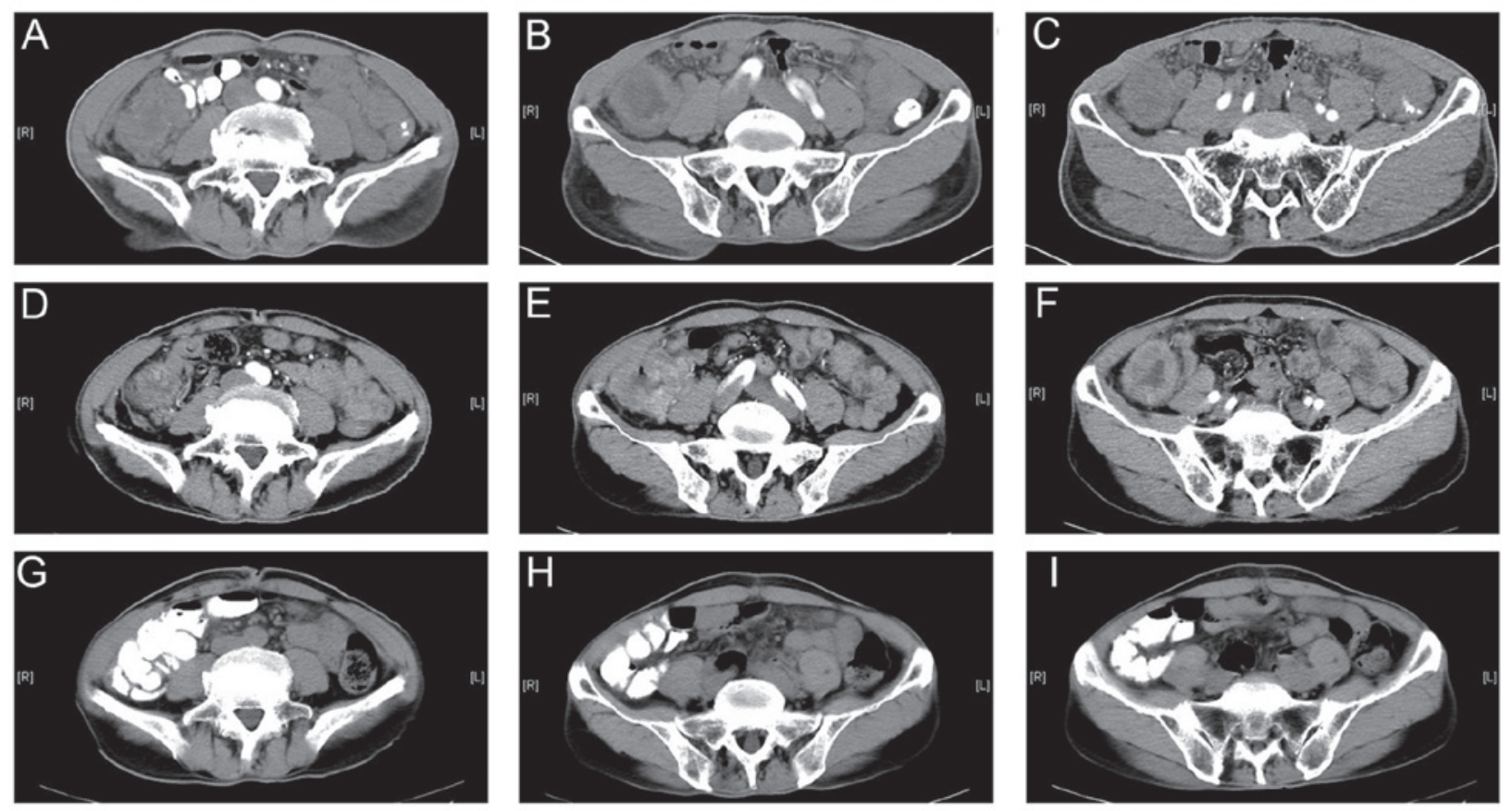

Figure 1. Computed tomography scan of the abdomen showing the changes in the colon lesion following neoadjuvant chemotherapy and surgery. (A-C) Images prior to chemotherapy; (D-F) images after two cycles of neoadjuvant chemotherapy; (G-I) images after six cycles of adjuvant chemotherapy. 

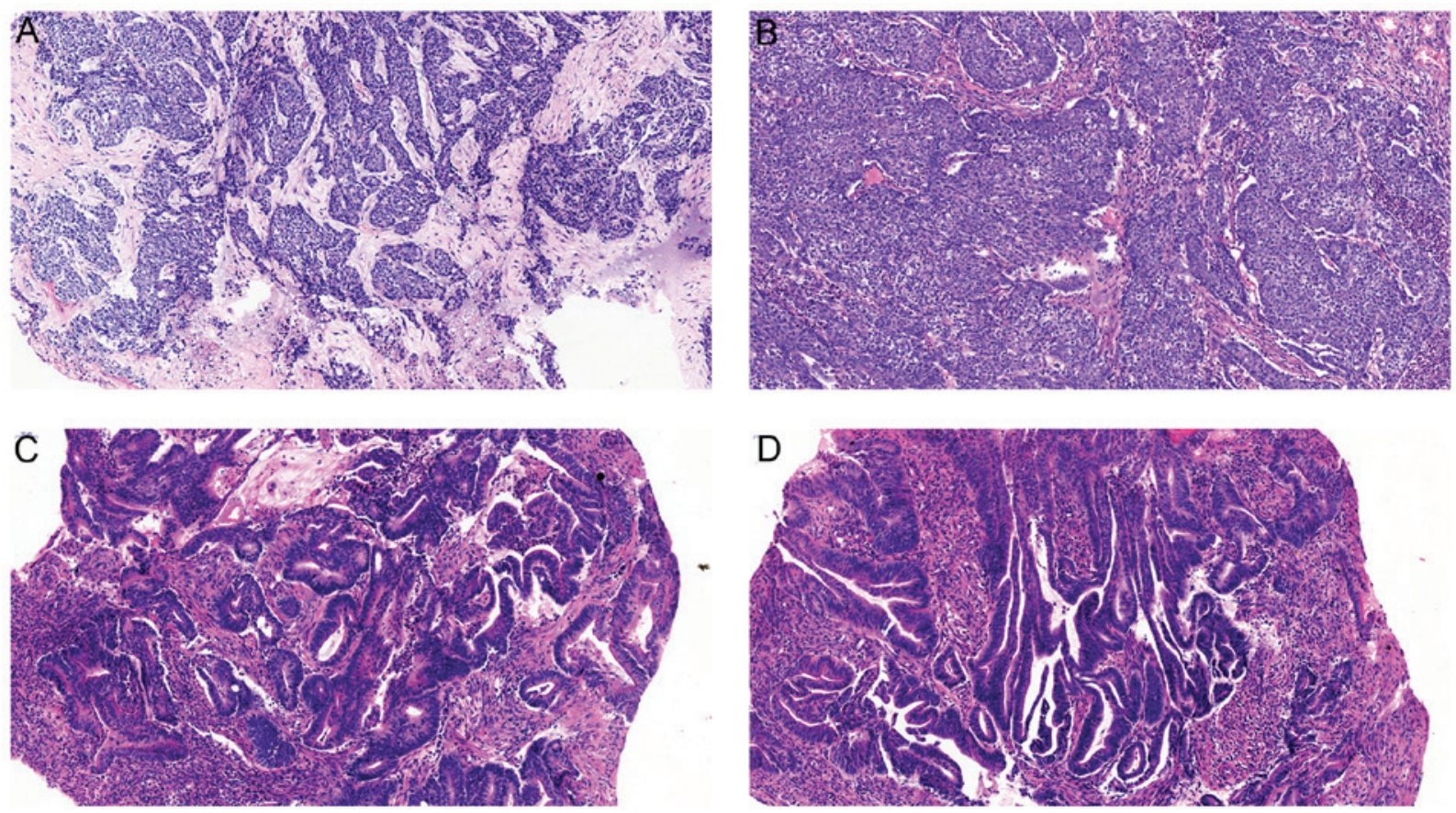

Figure 2. Microscopic findings. (A and B) The colon mass was composed of poorly differentiated squamous carcinoma cells; (C and D) the rectal mass was a moderately differentiated adenocarcinoma. Hematoxylin and eosin staining; magnification, x100.

cacy (Table IB). According to the World Health Organization criteria, the evaluation was stable disease.

On October 19th, 2015, the patient underwent radical right hemicolectomy and radical resection of rectal carcinoma (Dixon operation). The postsurgical pathology of the colon lesion revealed poorly differentiated SCC (ulcerative type) with infiltration of pericolic lymph nodes (1/22). The postsurgical pathology of the rectal lesion was moderately differentiated adenocarcinoma with no perirectal lymph node metastasis (0/13) (Fig. 2).

After surgery, the patient received six cycles of adjuvant chemotherapy within 2 months and remained disease-free (Figs. 1 and 3) up to the time this article was submitted (date of last follow-up, June 10th, 2016; follow-up time, 10.5 months).

\section{Discussion}

SCC is uncommon in the colon and rectum and was first reported by Herxheimer in 1907 (3). In 1927, White et al published the first report of primary adenosquamous cell carcinoma of the colon in the English medical literature (4). From then on, apart from a few small series from large institutions, the majority of the data comes from individual case reports (5-10).

Generally, SCC in the colon and rectum occurs in the anal canal, the lining of which is squamous epithelium, or in the lower part of the rectum adjacent to the anal canal, where it may originate from the nearby squamous or transitional cells. Adenosquamous carcinoma is a malignancy containing glandular and squamous histological components. However, the histogenesis of the squamous component remains unclear. There are several opinions as follows: i) Differentiation from stem cells (11-15); ii) squamous metaplasia (16-23); and iii) differentiation from adenocarcinoma (24-29).

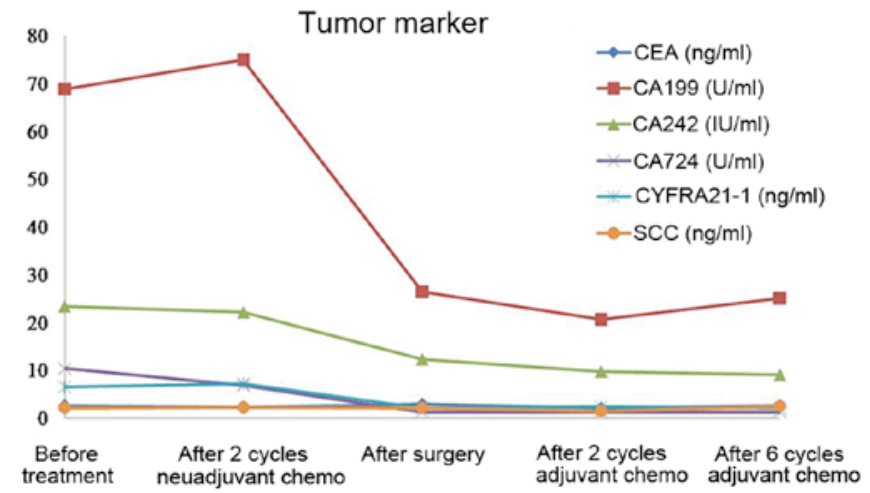

Figure 3. Gradual decrease in tumor marker levels during the treatment process. CEA, carcinoembryonic antigen; CA, carbohydrate antigen; CYFRA, cytokeratin-19 fragments; SCC, squamous cell carcinoma.

The optimal treatment for SCC has not been determined due to its low incidence. Generally, the treatment is based on that for adenocarcinomas, which is predominantly surgery combined with chemotherapy and radiotherapy. With the advances in chemotherapy and radiotherapy, the accuracy of determining stage and evaluating response, a multitude of recent studies utilizing various treatment regimens have been reported, which included 5-fluorouracil (5FU)/mitomycin C, $5 \mathrm{FU}, 5 \mathrm{FU} / \mathrm{cisplatin}$, capecitabine/cisplatin, capecitabine, raltitrexed/oxaliplatin and S-1 (10,11,30-52).

The most important prognostic predictor is cancer stage. Colorectal SCC follows the same route of lymphatic spread as adenocarcinoma; additionally, they share similar metastatic sites, such as the liver, lung and bone (53). In 1996, Petrelli et al described the cases of 5 men and 2 women diagnosed with adenosquamous carcinoma originating from the colon or rectum. All the patients were treated surgically. Chemotherapy 
was used as adjuvant treatment, or in patients with local recurrence and distant metastasis. The median overall survival was 23 months (7). In 1999, Cagir et al reported a review of 145 cases of adenosquamous carcinoma using the National Cancer Institute Surveillance, Epidemiology, and End Results database program over a 20-year period (1973-1992). Patients with localized disease (stages I and II) exhibited survival curves similar to those with comparably staged adenocarcinoma. Adenosquamous cancer patients with regional disease (stages IIB and III) had a shorter survival compared with patients with similar-stage colorecal adenocarcinoma. Patients with stage IV adenosquamous carcinoma had a significantly shorter survival compared with those with comparably staged adenocarcinoma (2). Frizelle et al published a report on 44 patients with adenosquamous carcinoma and SCC. In that study, they found the prognosis to be similar to that of colorectal adenocarcinoma for stage I-II node-negative disease. However, when nodal disease occurs, the prognosis is worse than that expected for adenocarcinoma of similar stage. The characteristics predicting a poor prognosis included rightsided lesions, ulcerated or annular carcinomas, node-positive disease, grade 3-4 cancer and stage IV disease (54).

Gemcitabine (2'-deoxy-2',2'-difluorocytidine monohydrochloride) is a potent and specific pyrimidine nucleoside antimetabolite, which is structurally analogous to deoxycytidine. In in vitro and phase I studies, gemcitabine had shown activity against various types of hematological and solid tumors (55-58). Furthermore, its antitumor activity had been confirmed in clinical practice. Gemcitabine has been used to treat patients with non-small-cell lung cancer, pancreatic, bladder and breast cancer, malignant mesothelioma and ovarian cancer. In preclinical studies, gemcitabine was found to act synergistically with a number of DNA-damaging agents, including platinum drugs and irradiation. Gemcitabine also has an extremely mild toxicity profile, which has prompted investigations of the agent in combination with other cytotoxic compounds. To the best of our knowledge, gemcitabine was selected as part of the chemotherapy regimen in colon SCC for the first time in the present case. As a result, the patient had achieved a PFS of 10 months by the time this article was submitted.

Colorectal SCC is rare, and its treatment is currently largely based on that applied for adenocarcinoma cases. As reported, SCC patients with stage III-IV disease have a poorer prognosis compared with those with adenocarcinoma. Thus, a more aggressive chemotherapeutic approach may be a viable choice for patients with a good performance status. In the present case, gemcitabine, oxaliplatin and capecitabine were selected as the chemotherapy regimen, which has never been reported in clinical practice. The PFS was 10 months until this manuscript was submitted. Thus, this new regimen may provide a reference for the future treatment for SCC of the colorectum.

\section{References}

1. Siegel RL, Miller KD and Jemal A: Cancer statistics, 2016. CA Cancer J Clin 66: 7-30, 2016.

2. Cagir B, Nagy MW, Topham A, Rakinic J and Fry RD: Adenosquamous carcinoma of the colon, rectum, and anus: Epidemiology, distribution, and survival characteristics. Dis Colon Rectum 42: 258-263, 1999.
3. Herxheimer G: Ober heterologue cancroide. Beitr Pathol Anat 41: 348-412, 1907.

4. White CP and Brunton CE: Some uncommon tumours. J Pathol 30: 313-330, 1927.

5. Crissman JD: Adenosquamous and squamous cell carcinoma of the colon. Am J Surg Pathol 2: 47-54, 1978.

6. Cerezo L, Alvarez M, Edwards O and Price G: Adenosquamous carcinoma of the colon. Dis Colon Rectum 28: 597-603, 1985.

7. Petrelli NJ, Valle AA, Weber TK and Rodriguez-Bigas M: Adenosquamous carcinoma of the colon and rectum. Dis Colon Rectum 39: 1265-1268, 1996.

8. Rajan R, Baqar A and Menon T: An interesting case of primary squamous cell carcinoma of the colon with synchronous metastatic adenocarcinoma. Clin Case Rep 2: 323-325, 2014.

9. Schneider TA II, Birkett DH and Vernava AM III: Primary adenosquamous and squamous cell carcinoma of the colon and rectum. Int J Colorectal Dis 7: 144-147, 1992.

10. Lyttle JA: Primary squamous carcinoma of the proximal large bowel. Report of a case and review of the literature. Dis Colon Rectum 26: 279-282, 1983.

11. 12. Nahas CS, Shia J, Joseph R, Schrag D, Minsky BD, Weiser MR, Guillem JG, Paty PB, Klimstra DS, Tang LH, et al: Squamous-cell carcinoma of the rectum: A rare but curable tumor. Dis Colon Rectum 50: 1393-1400, 2007.

12. Jaworski RC, Biankin SA and Baird PJ: Squamous cell carcinoma in situ arising in inflammatory cloacogenic polyps: Report of two cases with PCR analysis for HPV DNA. Pathology 33: 312-314, 2001.

13. Hicks JD and Cowling DC: Squamous-cell carcinoma of the ascending colon. J Pathol Bacteriol 70: 205-212, 1955.

14. Ouban A,Nawab RA and Coppola D: Diagnostic and pathogenetic implications of colorectal carcinomas with multidirectional differentiation: A report of 4 cases. Clin Colorectal Cancer 1: 243-248, 2002.

15. Michelassi F, Mishlove LA, Stipa F and Block GE: Squamous-cell carcinoma of the colon. Experience at the University of Chicago, review of the literature, report of two cases. Dis Colon Rectum 31: 228-235, 1988.

16. LeBlanc LJ, Buie LA and Dockerty MB: Squamous-cell epithelioma of the rectum. Ann Surg 131: 392-399, 1950.

17. Lugo M and Putong PB: Metaplasia. An overview. Arch Pathol Lab Med 108: 185-189, 1984.

18. Lee SD, Haggitt RC and Kimmey MB: Squamous metaplasia of the rectum after argon plasma coagulation. Gastrointest Endosc 52: 683-685, 2000.

19. Cabrera A and Pickren JW: Squamous metaplasia and squamouscell carcinoma of the rectosigmoid. Dis Colon Rectum 10: 288-297, 1967.

20. Woods WG: Squamous cell carcinoma of the rectum arising in an area of squamous metaplasia. Eur J Surg Oncol 13: 455-458, 1987.

21. Dukes CE: The Surgical Significance of the Unusual in the Pathology of Intestinal Tumours: Imperial Cancer Research Fund Lecture delivered at the Royal College of Surgeons of England on 23rd November, 1948. Ann R Coll Surg Engl 4: 1169-1170, 1949.

22. Reeve DRE: Squamous metaplasia in the healing of chronic colonic ulcers of the rat. J Pathol 117: 15-22, 1975.

23. Wells HG, Slye M and Holmes HF: Comparative Pathology of Cancer of the Alimentary Canal, with Report of Cases in Mice Studies in the Incidence and Inheritability of Spontaneous Tumors in Mice: 34th Report. Am J Cancer 33: 223-238, 1938.

24. Williams GT, Blackshaw AJ and Morson BC: Squamous carcinoma of the colorectum and its genesis. J Pathol 129: 139-147, 1979.

25. Chen KTK: Colonic adenomatous polyp with focal squamous metaplasia. Hum Pathol 12: 848-849, 1981.

26. Almagro UA, Pintar K and Zellmer RB: Squamous metaplasia in colorectal polyps. Cancer 53: 2679-2682, 1984.

27. Kontozoglou T: Squamous metaplasia in colonic adenomata: Report of two cases. J Surg Oncol 29: 31-34, 1985.

28. Forouhar F: Neoplastic colonic polyp with extensive squamous metaplasia. Case report. Tumori 70: 99-103, 1984.

29. Lundquest DE, Marcus JN, Thorson AG and Massop D: Primary squamous cell carcinoma of the colon arising in a villous adenoma. Hum Pathol 19: 362-364, 1988.

30. Theodosopoulos TK, Marinis AD, Dafnios NA, Vassiliou JG, Samanides LD, Carvounis EE and Smyrniotis VE: Aggressive treatment of metastatic squamous cell carcinoma of the rectum to the liver: A case report and a brief review of the literature. World J Surg Oncol 4: 49, 2006. 
31. Choi H, Lee HW, Ann HW, Kim JK, Kang HP, Kim SW, Ku NS, Han SH, Kim JM and Choi JY: A case of rectal squamous cel carcinoma with metachronous diffuse large B cell lymphoma in an HIV-infected patient. Infect Chemother 46: 257-260, 2014.

32. Martinez-Gonzalez MD, Takahashi T, Leon-Rodriguez E, Gamboa-Dominguez A, Lome C, Garcia-Blanco MC, Bezaury P and Moran MA: Case report of primary squamous carcinoma of the rectum. Revista de investigación clínica; organo del Hospital de Enfermedades de la Nutrición 48: 453-456, 1996.

33. Rasheed S, Yap T, Zia A, McDonald PJ and Glynne-Jones R: Chemo-radiotherapy: An alternative to surgery for squamous cell carcinoma of the rectum--report of six patients and literature review. Colorectal Dis 11: 191-197, 2009.

34. Iannacone E, Dionisi F, Musio D, Caiazzo R, Raffetto N, Banelli E: Chemoradiation as definitive treatment for primary squamous cell cancer of the rectum. World J Radiol 2: 329-333, 2010.

35. Funahashi K, Nemoto T, Koike J, Kurihara A, Shiokawa H, Ushigome M, Kaneko T, Arai K, Nagashima Y, Koda T, et al Chemoradiation therapy with S-1 for primary squamous cell carcinoma of the rectum: Report of three cases. Surg Case Rep 1: 14, 2015.

36. Wang MLC, Heriot A, Leong $T$ and Ngan SYK: Chemoradiotherapy in the management of primary squamouscell carcinoma of the rectum. Colorectal Dis 13: 296-301, 2011.

37. Ozuner G, Aytac E, Gorgun E and Bennett A: Colorecta squamous cell carcinoma: A rare tumor with poor prognosis. Int J Colorectal Dis 30: 127-130, 2015.

38. Jeong BG, Kim DY and Kim SY: Concurrent chemoradiotherapy for squamous cell carcinoma of the rectum. Hepatogastroenterology 60: 512-516, 2013.

39. Matsuda A, Takahashi K, Yamaguchi T, Matsumoto $H$, Miyamoto H, Kawakami M, Kawachi H, Suzuki H, Furukawa K, Tajiri T, et al: HPV infection in an HIV-positive patient with primary squamous cell carcinoma of rectum. Int J Clin Oncol 14 551-554, 2009

40. Brammer RD, Taniere P and Radley S: Metachronous squamouscell carcinoma of the colon and treatment of rectal squamous carcinoma with chemoradiotherapy. Colorectal Dis 11: 219-220, 2009.

41. Péron J, Bylicki O, Laude C, Martel-Lafay I, Carrie C and Racadot S: Nonoperative management of squamous-cell carcinoma of the rectum. Dis Colon Rectum 58: 60-64, 2015.

42. Gelas T, Peyrat P, Francois Y, Gerard JP, Baulieux J, Gilly FN, Vignal J and Glehen O: Primary squamous-cell carcinoma of the rectum: Report of six cases and review of the literature. Dis Colon Rectum 45: 1535-1540, 2002.

43. Al Hallak MN, Hage-Nassar G and Mouchli A: Primary Submucosal Squamous Cell Carcinoma of the Rectum Diagnosed by Endoscopic Ultrasound: Case Report and Literature Review. Case Rep Gastroenterol 4: 243-249, 2010.

44. Tronconi MC, Carnaghi C, Bignardi M, Doci R, Rimassa L, Di Rocco M, Scorsetti M and Santoro A: Rectal squamous cell carcinoma treated with chemoradiotherapy: Report of six cases. Int J Colorectal Dis 25: 1435-1439, 2010.
45. Kulaylat MN, Doerr R, Butler B, Satchidanand SK and Singh A: Squamous cell carcinoma complicating idiopathic inflammatory bowel disease. J Surg Oncol 59: 48-55, 1995.

46. Kassir R, Baccot S, Bouarioua N, Petcu CA, Dubois J, BoueilBourlier A, Patoir A, Epin A, Ripamonti B and Tiffet O Squamous cell carcinoma of middle rectum: Literature review. Int J Surg Case Rep 5: 86-90, 2014.

47. Berardi RS, Chen HP and Lee SS: Squamous cell carcinoma of the colon and rectum. Surg Gynecol Obstet 163: 493-496, 1986.

48. Pikarsky AJ, Belin B, Efron J, Woodhouse S, Weiss EG, Wexner $\mathrm{SD}$ and Nogueras JJ: Squamous cell carcinoma of the rectum in ulcerative colitis: Case report and review of the literature. Int J Colorectal Dis 22: 445-447, 2007.

49. Yeh J, Hastings J, Rao A and Abbas MA: Squamous cell carcinoma of the rectum: A single institution experience. Tech Coloproctol 16: 349-354, 2012.

50. Seshadri RA, Pancholi M, Jayanand SB and Chandrasekar S: Squamous cell carcinoma of the rectum: Is chemoradiation sufficient? J Cancer Res Ther 11: 664, 2015.

51. Musio D, De Felice F, Manfrida S, Balducci M, Meldolesi E, Gravina GL, Tombolini V and Valentini V: Squamous cell carcinoma of the rectum: The treatment paradigm. Eur J Surg Oncol 41: 1054-1058, 2015

52. Clark J, Cleator S, Goldin R, Lowdell C, Darzi A and Ziprin P: Treatment of primary rectal squamous cell carcinoma by primary chemoradiotherapy: Should surgery still be considered a standard of care? Eur J Cancer 44: 2340-2343, 2008.

53. Torricelli P: Rectal cancer staging. Surg Oncol 16 (Suppl 1): S49-S50, 2007.

54. Frizelle FA, Hobday KS, Batts KP and Nelson H: Adenosquamous and squamous carcinoma of the colon and upper rectum: A clinical and histopathologic study. Dis Colon Rectum 44: 341-346, 2001.

55. Abbruzzese JL, Grunewald R, Weeks EA, Gravel D, Adams T, Nowak B, Mineishi S, Tarassoff P, Satterlee W, Raber MN, et al: A phase I clinical, plasma, and cellular pharmacology study of gemcitabine. J Clin Oncol 9: 491-498, 1991.

56. Csoka K, Liliemark J, Larsson R and Nygren P: Evaluation of the cytotoxic activity of gemcitabine in primary cultures of tumor cells from patients with hematologic or solid tumors. Semin Oncol 22 (Suppl 11): 47-53, 1995.

57. Von Hoff DD; San Antonio Drug Development Team: Activity of gemcitabine in a human tumor cloning assay as a basis for clinical trials with gemcitabine. Invest New Drugs 14: 265-270, 1996.

58. Pollera CF, Ceribelli A, Crecco M, Oliva C and Calabresi F: Prolonged infusion gemcitabine: A clinical phase I study at low- $\left(300 \mathrm{mg} / \mathrm{m}^{2}\right)$ and high-dose $\left(875 \mathrm{mg} / \mathrm{m}^{2}\right)$ levels. Invest New Drugs 15: 115-121, 1997. 